\title{
EFFECTS OF HOGNA CAROLINENSIS AND PHIDIPPUS OCTOPUNCTATUS SPIDER VENOMS ON CULTURED HEART CELLS: MORPHOLOGICAL STUDIES
}

\author{
Faragalla*, A. A., S. M. Elassouli*, S.O. Al-Saggaf ${ }^{* *}$, \\ K. M. Al-Ghamdi* and A. M. Kelany*
}

*Dept. of Biological Sciences, Faculty of Science and **Dept. of Anatomy, Faculty of Medicine

King Abdul-Aziz University P.O Box: 80205, Jeddah, 21589 KSA

\begin{abstract}
:
The aim of this study is to investigate the effect of the venoms from wolf spider Hogna carolinensis and the Jumping spider Phidippus octopunctatus on the morphology and viability of cultured 1-2 days old rat embryonic cardiac cells. After treatment with spiders venom, marked morphological changes in cardiac cells were observed, illustrated by rounding-up of the cells, reduction in cell size, loss of cellular projections and clustering. This was followed by cell detachment from the substratum, as revealed by light microscopy. Cells proliferation were also susceptible to the toxic effect of both Hogna carolinensis and Phidippus octopunctatus, and it caused a significant time- and dose-dependent decrease in cell number when the cells were treated with $0.05,5,50$ or $200 \mathrm{ug} / \mathrm{ml}$ of the venom for five days.
\end{abstract}

\section{INTRODUCTION:}

There are over 34,000 species of spider world-wide (except Antarctica). Almost of all are fanged and venomous. Fortunately less than $0.5 \%$ are able to penetrate human skin and, of those, only a handful are considered dangerous. Most bites occurring when the spider is provoked or trapped. Spiders are predatory animals, which consume other animals (including other spiders), for food. For the vast majority of spider species, biting is the way by which a spider subdues its prey; the spider will use its venom to paralyze or kill its victim, often consuming it later. Spiders also use biting as a defensive mechanism; though the primary purpose of spider venom is to capture food ${ }^{[1-3]}$.

Spiders (Araneae) make up an integral component of the animal life of the vast and diversified land in terrestrial habitats in the hot dry domains and warm climates all over the world, offers ideal viability conditions for spinning especially in the Kingdom of Saudi Arabia $^{[4-6]}$.

The chief concern with the bite of medically significant spiders is the effect of the spider's 
venom. A spider envenomation occurs whenever a spider bites. Not all spider bites involve injection of venom into the wound. The amount of venom injected can vary based on the type of spider. With very few exceptions, such as the socalled camel spider (which is not a true spider), the mechanical injury from a spider bite is not a serious concern for humans. Some spider bites leave a large enough wound that infection may be a concern, and other species are known to consume prey which is already dead, which also may pose a risk for transmission of infectious bacteria from a bite ${ }^{[7,8]}$.

However, the toxicity of spider venom which poses the most risk to human beings; can be fatal to humans in the amounts that a spider will typically inject when biting ${ }^{[9,10]}$.

Many spider venoms contain peptide neurotoxins active on ion channels. One major class of such toxins is the gating modifiers which activate $\mathrm{Na}^{+}$channels by shifting their voltage dependence or removing inactivation or $\operatorname{both}^{[11,12]}$.

The cellular depolarization and/or repetitive firing of action potentials that results when these toxins act on neurons may explain many excitotoxic activities of such venoms and their components observed in vivo ${ }^{[13]}$ or in vitro ${ }^{[14]}$ as well as the liberation of neurotransmitters that these toxins induce in brain slices or synaptosomes $^{[15]}$. Similarly, stimulation of sensory neurons by the opening of $\mathrm{Na}^{+}$channels may cause, at least in part, the intense local pain reported by victims of some spider bites. The clinical manifestations of spider envenomation also include visual disturbances, priapism, neurogenic shock, tachycardia and arrhythmias. However, in Saudi Arabia there are no reports on severe human accidents by spiders of the suborder Mygalomorph. The symptoms are slight local pain, swelling and redness that disappeared after few hours. In severe cases, renal failure can occur leading to death, especially in children ${ }^{[16,17]}$.

Sphingomyelinase $D$ is the major component of Loxosceles venom, and has already been demonstrated to be the factor responsible for inducing dermonecrosis in humans, rabbits and guinea pigs. Sphingomyelinase $D$ cleaves the choline moiety of sphingomyelin, resulting in ceramide phosphate, in contrast to endogenous mammalian sphingomyelinases, which cleave the choline-phosphate moiety of sphingomyelin generating ceramide itself ${ }^{[18]}$.

It is well known that ceramides, the breakdown products resulting from the action of sphingomyelinases on sphingomyelin, are very important cellular regulators of various biological processes such as proliferation, migration, differentiation and apoptosis ${ }^{[19]}$. Sphingomyelin (N-acylsphingosine-1-phosphocholine or ceramide phosphocholine) the primary source of ceramide in signal transduction, is preferentially concentrated in the outer leaflet of the plasma membrane of mammalian cells ${ }^{[20]}$.

However, the inner leaflet of the plasma membrane or lysosomal/endosomal compartment may be functionally a more important site for sphingomyelin hydrolysis and ceramide generation, given the necessity for interaction between ceramide and intracellular targets. 
Ceramides also regulate TNF- $\alpha$ production that causes vascular endothelial cells to express adhesion molecules for leukocytes and stimulates endothelial cells and macrophages to secrete chemokines such as IL-8, the most potent chemotactic factor for neutrophils.

\section{MATERIAL AND METHODS:}

\section{Preparation of Spider Venoms:}

$\begin{array}{rrcr}\text { Wolf } & \text { spider Hogna carolinensis } & \text { and } \\ \text { Phidippus } & \text { octopunctatus } & \text { venoms were }\end{array}$ purchased from Spider Pharm, Arizona, USA. The venom was kept in a desiccators in the refrigerator until used.

\section{Embryonic Rat Heart Cell Culture:}

Wistar rat embryo hearts 1-2 days old were removed under sterile conditions and washed three times with phosphate buffer saline (PBS) and once with minimal essential media (MEM) with out serum. The hearts cells were prepared as described ${ }^{[21,22]}$. Briefly, heart were cut into small fragments, minced and then gently agitated in trypsin solution at a concentration of $0.025 \mathrm{mg} / \mathrm{ml}$. The supernatant suspensions containing the dissociated cells was removed and cells were collected by centrifugation at 100 xg. Cells were resuspended in MEM containing $10 \%$ heat inactivated $\left(56^{\circ} \mathrm{C}\right.$ for $\left.30 \mathrm{~min}\right)$ foetal calf serum and $5 \mathrm{mg} / \mathrm{ml}$ glucose. Cells were adjusted to $5 \times 10^{4}$ cells $/ \mathrm{ml}$ and plated into $35 \mathrm{~mm}$ culture dishes and incubated in a humidified incubator in an atmosphere of $5 \% \mathrm{CO}_{2}$ at $37^{\circ} \mathrm{C}$.

\section{Cells Exposure to Venoms:}

Heart confluent mono layers cells were washed and adjust to $5 \times 10^{4}$ cells $/ \mathrm{ml}$. Cells were seeded into 96-well cell culture plates at a concentration of $5 \times 10^{4}$ cells $/ \mathrm{ml}$ incubated in humidified $5 \% \quad \mathrm{CO}_{2}$ incubator. Cells were left to adjust for $\mathbf{2 4} \mathrm{hr}$ before the venoms were added. Venoms used were dissolved in MEM. The venoms concentrations used were selected based on previous reports on $\mathrm{LD}_{50}$ in optimization bioassays 0.01-10 $\mu \mathrm{g} / \mathrm{ml}$ venom for animals and also on our preliminary toxicity studies on cultured cells. Each venom was used at four different concentrations: $0.05 \mathrm{ug} / \mathrm{ml}, 5 \mathrm{ug} / \mathrm{ml}, 50$ ug/ml, and $200 \mathrm{ug} / \mathrm{ml}$. Cells were maintained with the venoms for 5 days.

\section{Morphological studies:}

Venoms treated cells were harvested by centrifugation at $100 \mathrm{x} \mathrm{g}$ for $5 \mathrm{~min}$. The pelleted cells were resuspended in the remaining solution and treated with $2 \mathrm{ml}$ of hypotonic solution (0.075 M KCL) drop wise at $37^{\circ} \mathrm{C}$ for 7 minutes. Cells were collected by centrifugation and the pellets were gently resuspended in the remaining fluid. Two drops of the cell suspension were spread on dry slide angled at $45^{\circ}$, fixed in methanol for 2 seconds and air dried $^{[21]}$. Slides were stained with Giemsa and examined under light microscope.

\section{Cytotoxicity Assay:}

In this study we investigated the effect of Wolf spider Hogna carolinensis and Phidippus octopunctatus venoms on Wistar rat embryonic heart cells grown in culture. Cells were exposed to venoms at different concentrations. Four concentrations were used for each venom $(0.05$, 
5, 50, and $200 \mathrm{ug} / \mathrm{ml}$ ) Control was a well containing cell grown in absence of venom. Cells were maintained with the venoms for the period of the experiment, and cell viability was determined every day after venoms treatment for five days. Cells were harvested with trypsin; EDTA and viable cells were counted by trypan blue exclusion test ${ }^{[23]}$ and determined by hemocytometer. All assays were set up in duplicate for each concentration.

\section{RESULTS AND DISCUSSION:}

\section{Morphological Changes Induced by Venoms:}

Marked morphological changes of cultured rat embryonic cardiac cells were observed when exposed to $\boldsymbol{H}$. carolinensis and $\boldsymbol{P}$. octopunctatus spider venoms at concentrations of $0.05-200$ ug/ml.

The gross microscopic response to the two spider venoms was initial rounding-up of the cells, reduction in cell size and loss of cellular projections followed by detachment from the cell culture surface and clustering (Figs.1-3). The morphological changes showed dose-related responses by the cardiac cells in both. The $H$. carolinensis and $\boldsymbol{P}$. octopunctatus venoms.

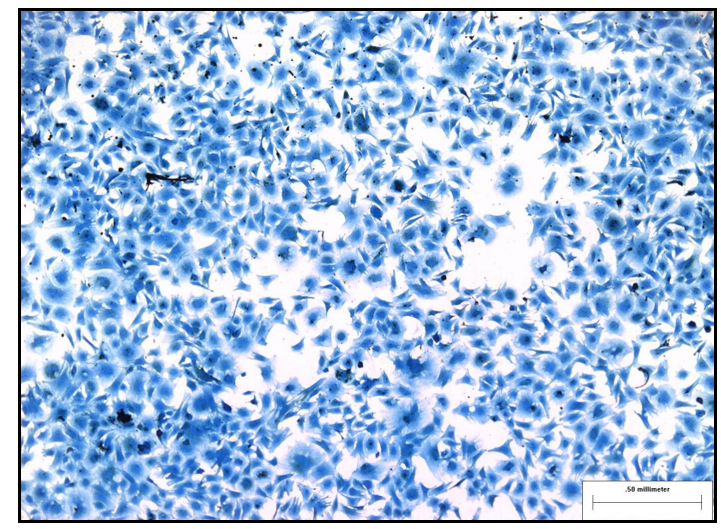

A

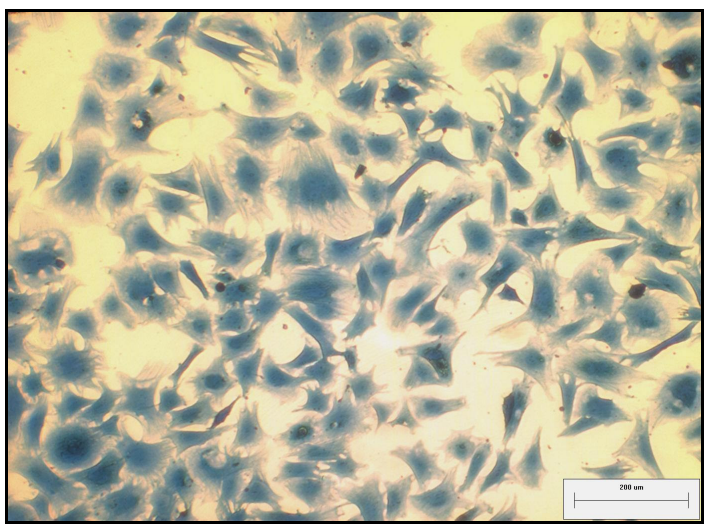


B

Fig. 1 A\&B: Rat embryonic cardiac cells untreated with venom (control), showing nice confluent monolayer attached cells, spindle shape with projections 


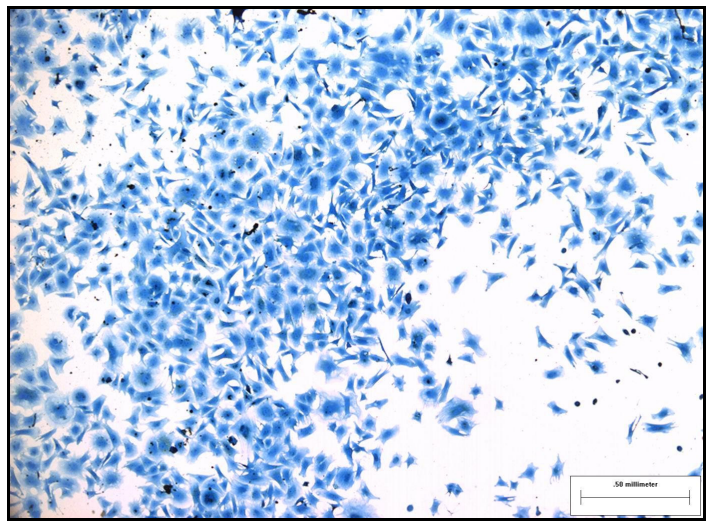

A-day 1 following venom treatment

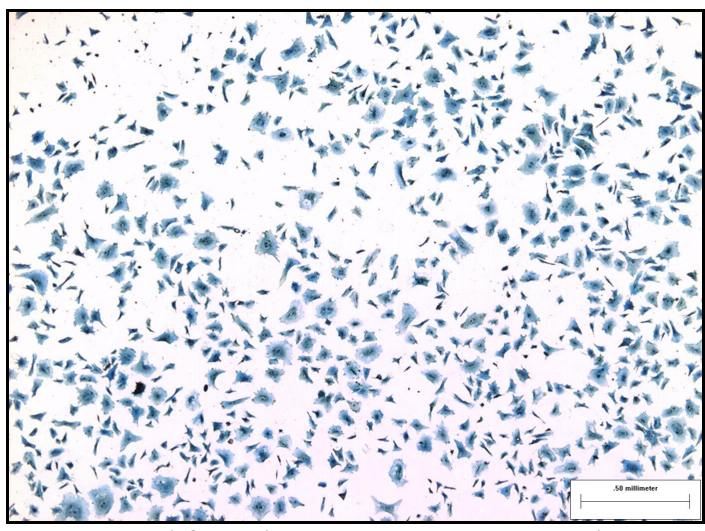

B-Day 3 following venom treatment showing reduction in cell number

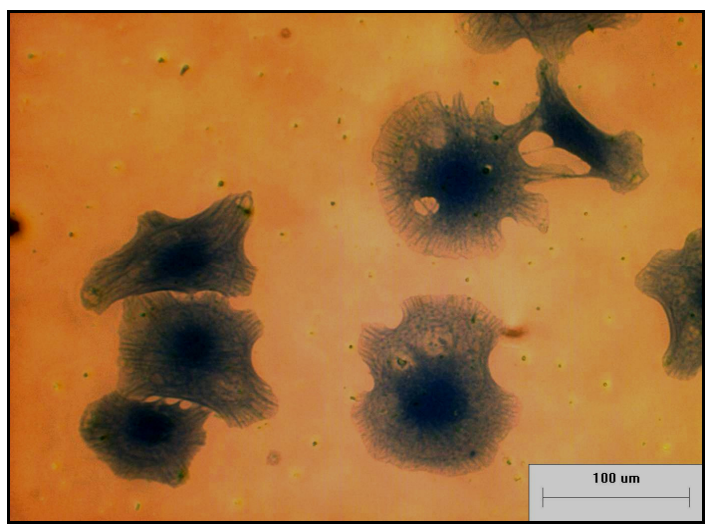

C-Magnified cells 3 days following venom treatment showing rounding of cells, loss of spindle shape and projections. Also, cells had less contact with each other

Fig. 2: Rat embryonic cardiac cells treated with Hogna carolinensis_venom 


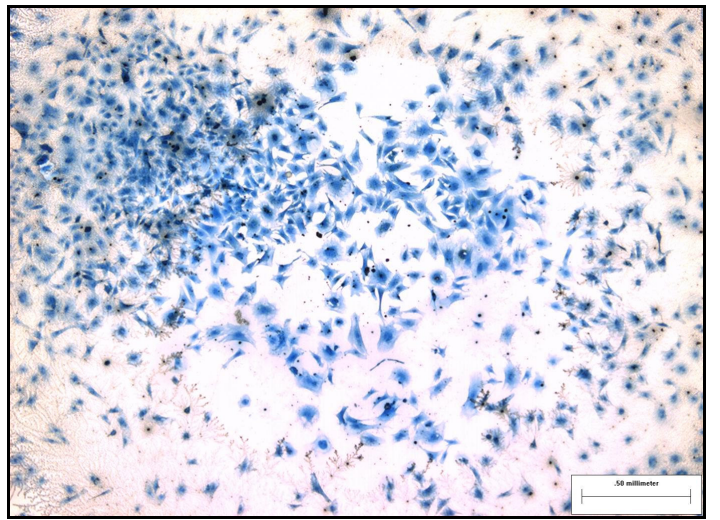

A-Day 1 following venom treatment

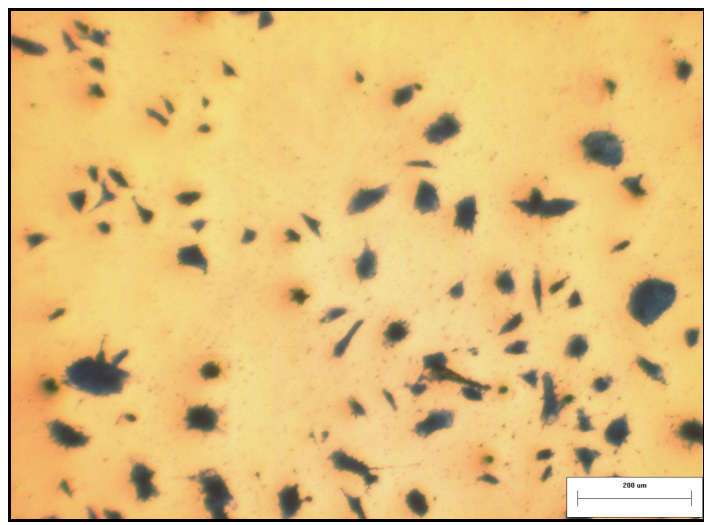

C-Magnified cells 4 days following venom treatment

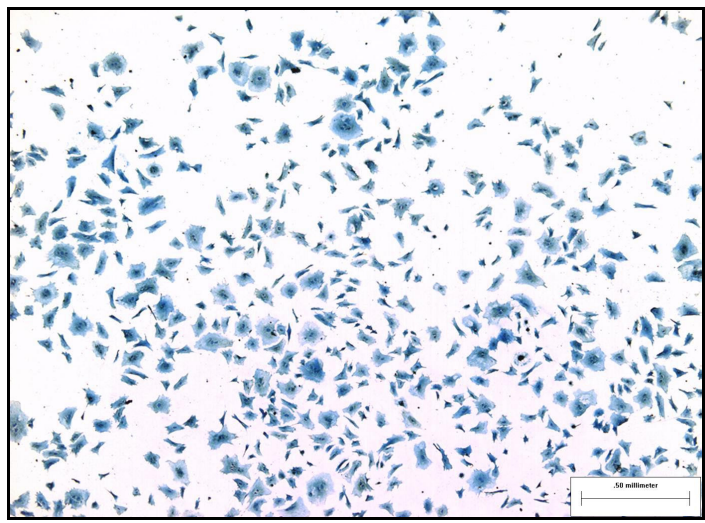

B-Day 3 following venom treatment showing reduction in cell number

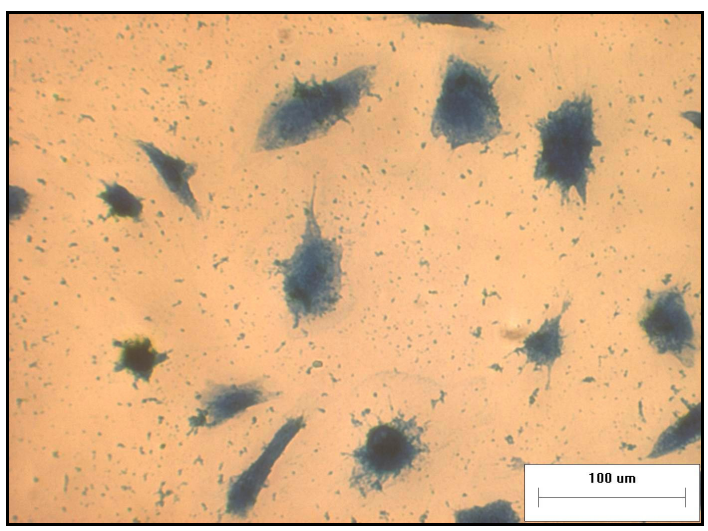

D-cardiac cells showing rounding of cells, loss of spindle shape and projections following treatment with the venom. Also, cells had less contact with each other

Fig. 3: Rat embryonic cardiac cells treated with Phidippus octopunctatus venom

\section{Effect of Venoms on Growth Rate and Cell Viability:}

Spider venoms at concentrations of 0.05 $200 \mu \mathrm{g} / \mathrm{ml}$ caused dose- and time-dependent inhibition of cultured cardiac cells proliferation. The effect of 5 days exposure to Hogna carolinensis venom on the growth of embryonic rat cardiac cells is shown in Figure 4. The extent of growth inhibition was dose dependent and cells treated with venom grew at a slower rate than the untreated control cells. The venom acts very rapidly and by the third day of incubation at concentrations of $50 \mathrm{ug} / \mathrm{ml}$ and $200 \mathrm{ug} / \mathrm{ml}$ more than $90 \%$ of cell growth was inhibited (Fig. 4A).

Similarly the Cytotoxicity of Phidippus octopunctatus venom was at its maximum at $\mathbf{5 0}$ ug/ml and $200 \mathrm{ug} / \mathrm{ml}$ causing more than $93 \%$ 
cell growth inhibition after 5 days of exposure to the venom (Fig. 4B). Phidippus octopunctatus venom act more rapidly than Hogna carolinensis venom, after $24 \mathrm{hr}$ of exposure, $P$. octopunctatus $200 \mathrm{ug} / \mathrm{ml}$ caused $80 \%$ cell growth inhibition, meanwhile $H$. carolinensis caused only $56 \%$ cell growth inhibition. Also, the P.octopunctatus venom is more cytotoxic to the cultured cardiac cells and it showed more toxicity at a lower venome concentrations compare to $H$. carolinensis venom (Fig. 4 a\&B). The inhibition of cardiac cells by the venoms of the spider could be due to apoptosis, toxicity damage or direct lyses. Additional biochemical studies are needed to delineate that.

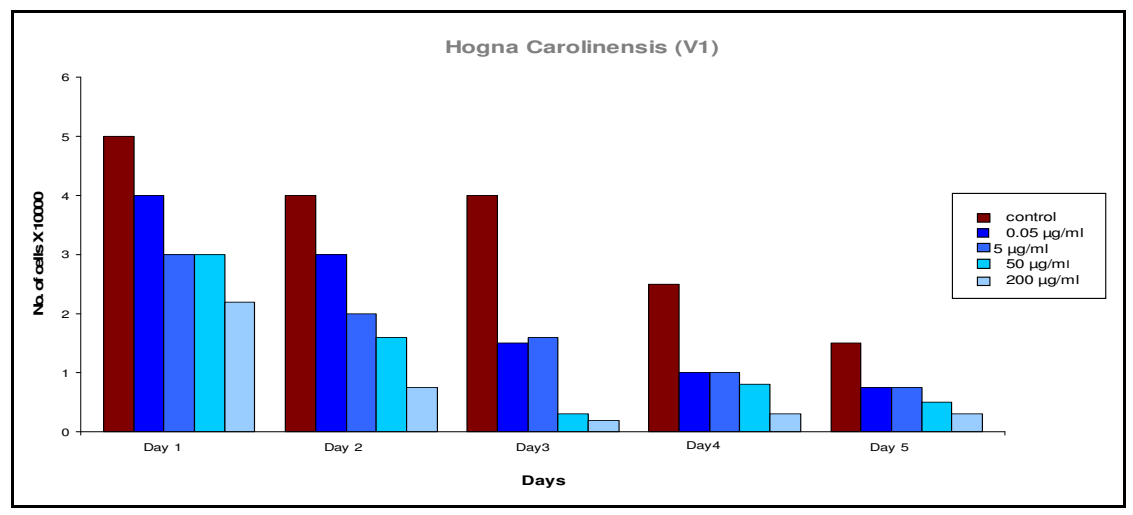

A

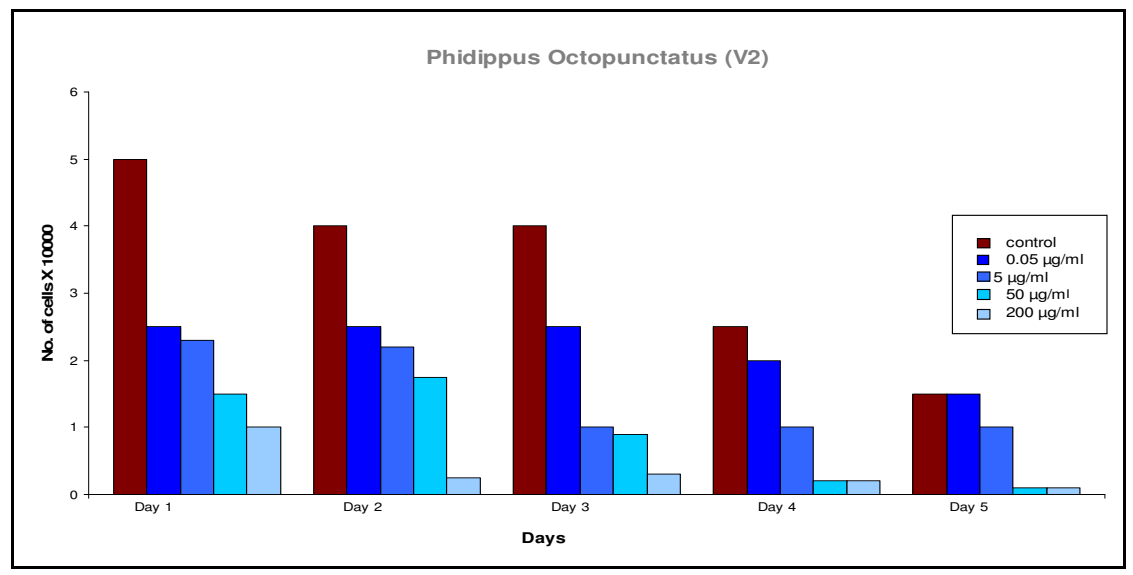

B

Fig. 4: Effect of (A) Hogna carolinensis venom and (B) Phidippus octopunctatus on viability of rat embryonic cardiac cells. Cardiac cells were seeded in a 96-well cell culture plate at a density of $5 \times 10^{4}$ cells $/ \mathrm{ml}$ and left to settle at $37{ }^{\circ} \mathrm{C}$ in a $5 \% \mathrm{CO}_{2}$ incubator overnight. Cells were exposed to $0.05,5,50$, and $200 \mathrm{ug} / \mathrm{ml} \mathrm{of} \mathrm{venoms} \mathrm{in}$ tissue culture medium. Parallel wells were incubated with cells without venom as a control 


\section{Acknowledgment:}

The authors would like to extend their thanks to Mr. Zaki Elassouli for his efforts on all technical lab services. Also thanks goes to Dr. Huda Al Darib for providing the experimental material.Finally, gratitude is extended to the Deanship of Scientific Research at King Abdul Aziz University for funding this research project.

\section{REFERENCES:}

1-Wilson D.C. and King L.E, Jr. (1990): Spiders and spider bites. Dermatol. Clin. 8:277-286.

2-Zukoski, C. W. (1993): Black widow spider bite. J. Am. Board fam. Pract.6:279-281.

3-Holz, G.G. and Habener, J.F. (1998): Black widow spider alpha-latrotoxin: a presynaptic neurotoxin that shares Structural homology with the glucagons-like peptide-1 family of insulin secretagogic hormones. Comp. Biochem Physiol. B. Biochem. Mol. Biol. 121:177-184.

4-Faragalla, A.A. and Taher, M.O. (1989): True spiders ( Araneae ) in the Western region of Saudi Arabia. Scientific Publication Centre. King Abdulaziz University, Jeddah 18p.

5-Faragalla, A.A. and K.M. Al Ghamdi (2001a): A study on relative abundance of the wolf spiders (Araneae: Lycosidae) in Western Saudi Arabia. Arch. Phytopaht. Pflanz. 34:123-132.

6-Al Ghamdi, K.M. and A.A. Faragalla (1999): Occurrence of jumping spiders (Araneae : Salicidae) in alfalfa agroceosystems, in Western Saudi Arabia. Arab Gulf J. Scientific Res.17:245-254.
7-Punzo, F. (1998): The Biology of CamelSpiders. Kluwer Academic Publishers.

8-De Oliveira, K.C.; Goncalves de Andrade, R.M.; Piazza, R.M. Ferreira, J. M. Jr.; van den Berg, C.W. and Tambourgi, D.V. (2005): Variations in Loxosceles spider venom composition and toxicity contribute to the severity of envenomation. Toxicon.45:421-9.

9-Elston, D.M.; Eggers, J.S.; Schmidt, W.E. Storrow, A.B. Doe, R.H. McGlasson, D. Fischer, J.R. (2000): Histological findings after brown recluse spider envenomation. Am. J. Dermatopathol. 22: 242-246.

10-Ribeiro, A.M.; dos-Santos, W. F. and GarciaCaivasco, N. (2000): Neuroethological analysis of the effects of spider venom from Scaptocosa raptorial (Lycosidae: Araneae) microinjected in the lateral ventricle of Wistar rats. Brain- Res. Bull. 52: 581-588.

11-Araujo, D.A., M.N. Cordeiro, C.R. Diniz and P.S. Beirao (1993): Effects of a toxic fraction, PhTx2, from the spider Phoneutria nigriventer on the sodium current. Naunyn Schmiedebergs Arch Pharmacol. 347:205208.

12-Cruz-Hofling, M.A., S. Love, G. Brook and L.W. Duchen (1985): Effects of Phoneutria nigriventer spider venom on mouse peripheral nerve. Q. J. Exp. Physiol. 70: 623-640.

13-Cordeiro, M., C.R. Diniz, A. Valentim, V.R. von Eickstedt, J. Gilroy and M. Richardson (1992): The purification and amino acid sequences of four Tx2 neurotoxins from the venom of the Brazilian armed spider Phoneutria nigriventer (Keys). FEBS Lett. 310:153-156. 
14-Fontana, M.D. O. Vital-Brazil and O. VitalBrasil (1985): Mode of action of Phoneutria nigriventer spider venom at the isolated phrenic nerve-diaphragm of the rat. Braz. J. Med. Biol. Res. 18: 557-565.

15-Barbaro, K.C., J.L.C. Cardoso, V.R.D. Eickstedt and I. Mota (1992): Dermonecrotic and lethal components of Loxosceles gaucho spider venom. Toxicon. 30:331-338.

16-Málaque, C.M., J.E. Castro-Valencia, J.L. Cardoso, F.O. França, K.C. Barbaro and

H.W. Fan. (2002): Clinical and epidemiological features of definitive and presumed loxoscelism in São Paulo. Braz. Rev. Inst. Med. Trop. São Paulo 44:139-143.

17-Sezerino, U.M., M. Zannin, L.K. Coelho, J. Gonçalves, Jr., M. Grando, S.G. Mattosinho, J.L.C. Cardoso, V.R.D. Eickstedt, F.O.S. França, K.C. Barbaro and H.W. Fan. (1998): A clinical and epidemiological study of Loxosceles spider envenoming in Santa Catarina. Braz. Trans. R. Soc. Trop. Med. Hyg. 92:546-548.
18-Ballou, L.R., S.J.F. Laulederkind, E.F. Roloniec and R. Raghow, (1996): Ceramide signalling and the immune response. Biochim. Biophys. Acta.1301: 273-287.

19-Hannun, Y.A. (1994): The sphingomyelin cycle and the second messenger function of ceramide. J. Biol. Chem. 269, pp. 3125-3128.

20-Barenholz, Y. and T.E. Thompson (1980): Sphingomyelins in bilayers and biological membranes. Biochim. Biophys. Acta. 604: 129-158.

21-Mitcheson, J.S., Hancox, J.C., Levi, AJ. (1998): Cultured adult cardiac myocytes: future applications, culture methods, morphological and electrophysiological properties. Cardiovasc. Res. 39: 280-300.

22-Harary, I., Farely, B. (1963): In vitro studies on single beating rat heart cells. Exp. Cell Res. 29: 451-465.

23-Cook, J.A. and I.B. Mitchell (1989): Viability measurements in mammalian cell system. Anal. Biochem., 179: 1-2. 


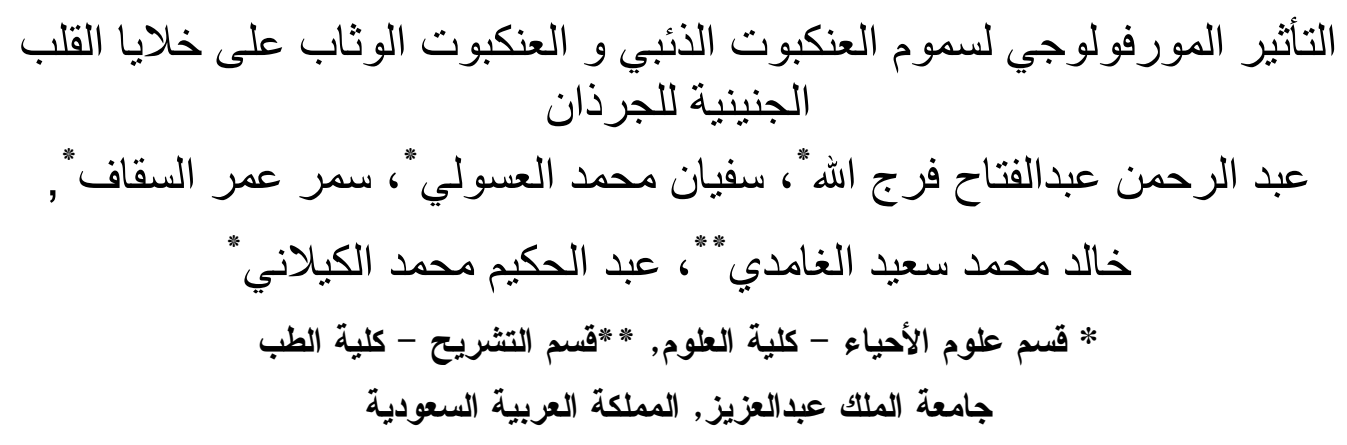

من أهداف هذه الاراسة معرفة مدى تأثير سم العنكبوت الأنبي والعنكبوت الوثاب على قدرة نمو خلايا القلب

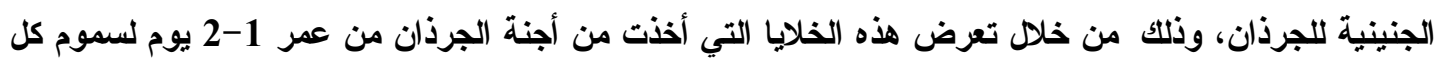

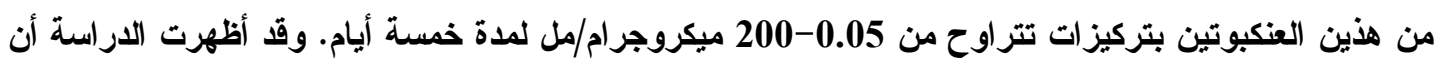

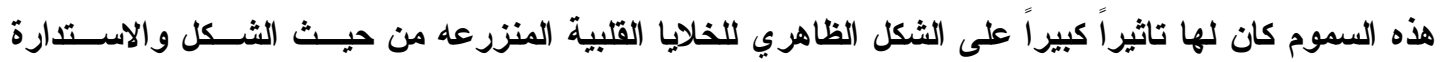

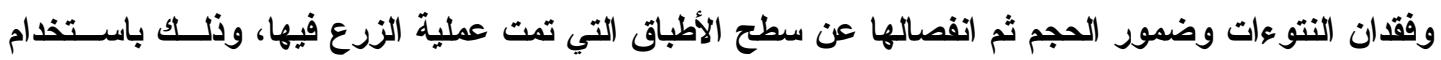

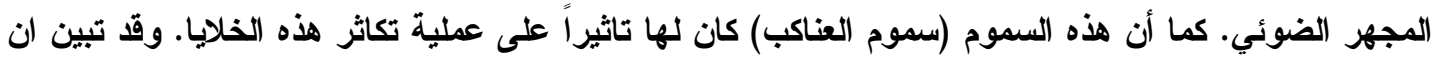

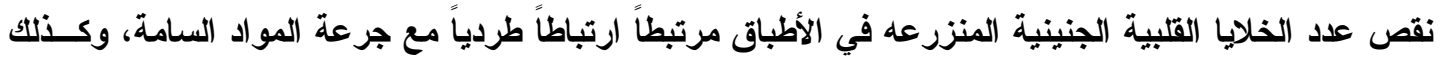
مع وقت التعرض لهذه السموم. 